\title{
Role of commensal and probiotic bacteria in human health: a focus on inflammatory bowel disease
}

Rebeca Martín ${ }^{1,2}$, Sylvie Miquel ${ }^{1,2}$, Jonathan Ulmer ${ }^{1,2}$, Noura Kechaou ${ }^{1,2}$, Philippe Langella ${ }^{1,2}$ and Luis G Bermúdez-Humarán ${ }^{1,2^{*}}$

\begin{abstract}
The human gut is one of the most complex ecosystems, composed of $10^{13}-10^{14}$ microorganisms which play an important role in human health. In addition, some food products contain live bacteria which transit through our gastrointestinal tract and could exert beneficial effects on our health (known as probiotic effect). Among the numerous proposed health benefits attributed to commensal and probiotic bacteria, their capacity to interact with the host immune system is now well demonstrated. Currently, the use of recombinant lactic acid bacteria to deliver compounds of health interest is gaining importance as an extension of the probiotic concept. This review summarizes some of the recent findings and perspectives in the study of the crosstalk of both commensal and probiotic bacteria with the human host as well as the latest studies in recombinant commensal and probiotic bacteria. Our aim is to highlight the potential roles of recombinant bacteria in this ecosystem.
\end{abstract}

Keywords: Bacteria-host crosstalk, Dysbiosis, Genetically modified microorganisms

\section{Relationship humans-bacteria: a history of common benefits}

The human gastrointestinal tract (GIT) is one of the most complex ecosystems known. Its microbiota consists of a large number of bacteria (10-fold more than the total number of human cells) that shapes many important physiological and metabolic processes as well as the development of the immune system [1,2]. The advances of molecular techniques have shown that the collective adult human GIT microbiota is composed of up to $1000-1150$ bacterial species $[3,4]$. The most frequently found species are Gram-positive bacteria. The predominant species (46-58\%) are those with low GC-content and the Clostridium group is the most abundant in this complex ecosystem [4]. Physiological conditions differ widely in the human GIT leading to an individual gut microbiota [5]. Some studies suggest that the faecal microbiota does not necessarily represent the bacteria inside the GIT [6-8]. Additionally, the intestinal lumen microbiota differs

\footnotetext{
* Correspondence: luis.bermudez@jouy.inra.fr

${ }^{1}$ INRA, UMR1319 Micalis, F-78350 Jouy-en-Josas, France

${ }^{2}$ AgroParisTech, UMR Micalis, F-78350 Jouy-en-Josas, France
}

significantly from the one in the mucus layer and near the epithelium due to the poor accessibility of the crypts covered by mucins [9].

Despite its complexity, the faecal microbiota of adult human individuals is unique and highly stable through time [10]. Primocolonizing microorganisms appear in the gut immediately after birth in an organized and lifelong process [11]. During the first year, after the initial establishment of the intestinal microbiota, its composition is relatively simple and varies between individuals [12]. After that, the main dominant groups of the adult microbiota will be conserved between all individuals. These groups are stable in spite of the great number of factors that can affect them [13]. In contrast, at the phylum level, the variation is higher between individuals although people who are related tend to have similar microbiota perhaps due to a shared environment and genetic similarities [13].

This microecosystem, which is a direct consequence of the mutualism between the host and its microbiota, is fundamental for the maintenance of the homeostasis of a healthy individual [5]. Commensal bacteria provide the host with essential nutrients. They metabolize indigestible 
compounds, defend against colonization of opportunistic pathogens and contribute to the development of the intestinal architecture as well as stimulation of the immune system among others [11]. Conversely, the host provides the bacteria with nutrients and a stable environment [5] (Figure 1). Both host and indigenous microorganisms have then adapted to each other in a particular case of microevolution to maintain the benefits that this mutualism confers [2].

\section{Probiotics: an additional bacterial advantage for humans}

Probiotics are defined as "live microorganisms which when administered in adequate amounts confer a health benefit on the host" [14]. This concept is based on the observations made by Élie Metchnikoff in 1907 in which the regular consumption of Lactic Acid Bacteria (LAB) in fermented dairy products, such as yogurt, was associated with enhanced health and longevity in many people living in Bulgarian villages [15].
Most probiotics belong to LAB, but new species and genera are being assessed for future use. Some other wellknown probiotics are Bifidobacterium sp., one strain of the Gram-negative bacterium Escherichia coli Nissle 1917 and the yeast Saccharomyces boulardii [16].

However, not all microorganisms are beneficial and screenings in order to identify novel candidate probiotics with immunomodulatory properties are frequently performed [17]. In fact, a Dutch trial using a probiotic preparation in patients with acute pancreatitis showed to be harmful [18]. These negative results show how important it is to choose the right protocol (indeed, the main problem with this study was the bad idea to administer massive quantitites of probiotics in very vulnerable patients) and to make a careful selection when using probiotics in humans. Certainly, a supposed beneficial effect of a specific strain cannot be extrapolated to another strain even within to the same species $[19,20]$.

Modulation of host immunity and promotion of host defense are the most commonly supported benefits of

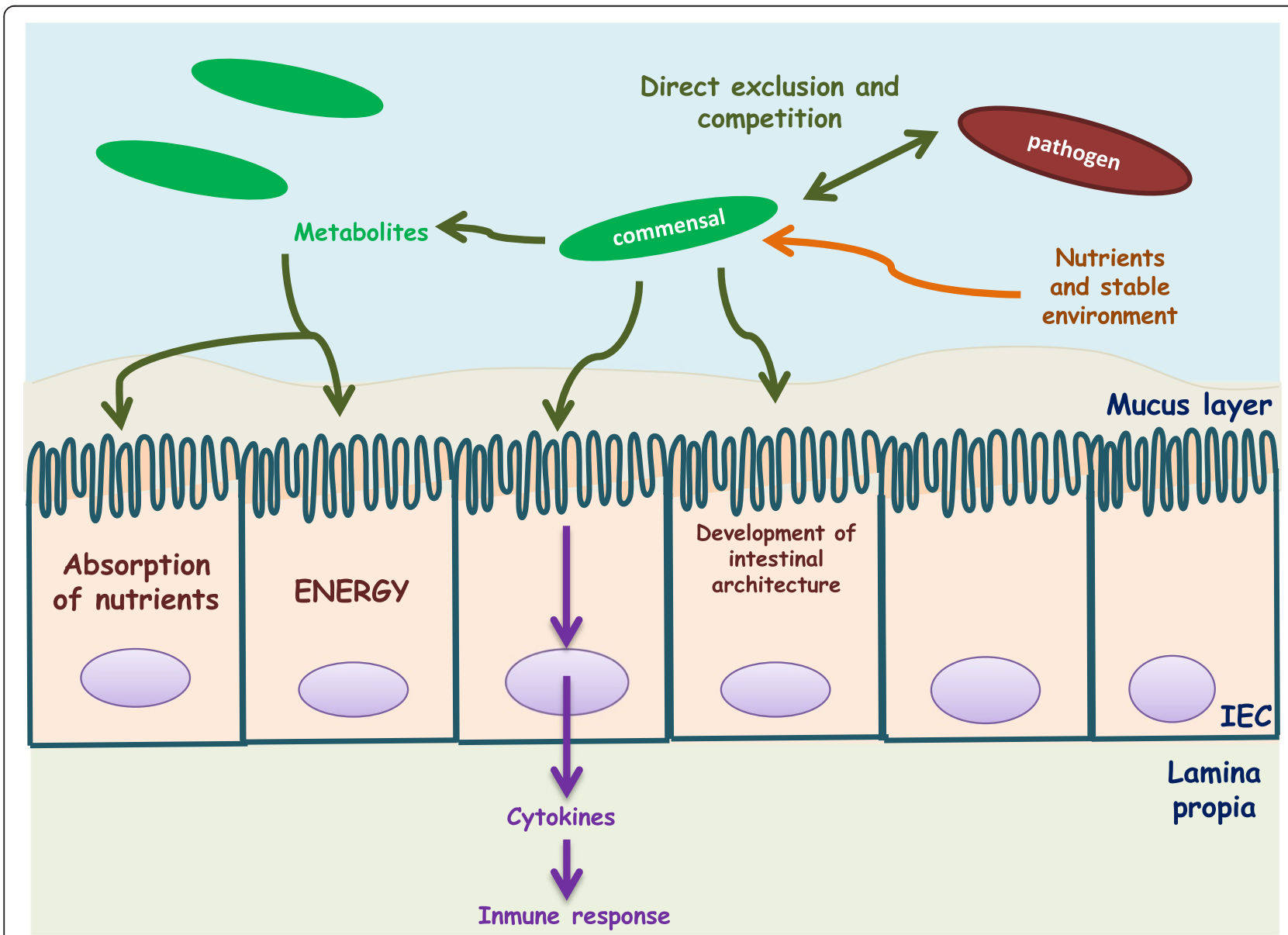

Figure 1 Commensal bacteria cross talk with the host. Commensal bacteria supply the host with essential nutrients and defend the host against opportunistic pathogens. They are involved in the development of the intestinal architecture and immunomodulatory processes. On the other hand, the host provides the bacteria with nutrients and a stable environment. 
the consumption of probiotics. For a microorganism to be considered probiotic (i.e. bacteria or yeast), the following criteria need to be fulfilled: i) it should have a clear beneficial effect on the host, ii) it should be nonpathogenic, iii) it should be able to survive transit through the GIT and iv) a large number of viable bacteria must be able to survive prolonged periods (i.e. upon storage) [21].

\section{What happens if homeostasis is broken?}

The term dysbiosis refers to microbial imbalances on or within the body. When homeostasis (balanced microbial ecosystem) is broken, different subdominant opportunistic bacteria can grow leading to a situation of illness. Additionally, when commensal bacteria are depleted, an abnormal health situation can be triggered due to a lack of the benefits these bacteria provide rather than the overgrowth of pathobionts.

a) Binomial dysbiosis - illness

The term dysbiosis has been related to many different kinds of pathologies although it is not clear whether the imbalance of microbiota is a cause or a consequence of the illness. The clearest correlation between dysbiosis and disease has been found with inflammatory bowel diseases (IBD) where the proportion of Firmicutes, in particular Faecalibacterium prausnitzii, was found to be low in patients that exhibited endoscopic recurrence 6 months after surgery [22,23]. IBD, including Crohn's disease (CD) and ulcerative colitis (UC), are characterized by an abnormal activation of the immune system associated with the gut, resulting in a chronic inflammation of the digestive system.

However, some other factors also seem to be involved in IBD such as genetic components [24,25], immunological disorders [26], environmental factors $[27,28]$, pathogens $[29,30]$, and microbiota [10]. Faecal analyses have shown a quantitative and qualitative reduction in the representation of the Firmicutes phylum, mostly the clostridial cluster IV members in CD patients while low numbers of total lactobacilli have been reported in UC members $[31,32]$, although no correlation was found between F. prausnitzii abundance and the severity of CD [33]. Even if the composition of the human microbiota is different in each individual, changes in phylogenic distribution have also been specifically found in obese and diabetic individuals versus normal ones $[34,35]$ (Table 1). The importance of the human microbiota has been demonstrated in the hygiene hypothesis, defined in 1989 by Strachan [36] who postulated that low exposure to infectious agents in early life explains the increased numbers of people suffering from allergies and asthma in developed countries. This hypothesis suggests that a well-balanced human microbiota is a factor that protects from such pathologies $[37,38]$.

Some microbial activities have shown relevance to health and disease. Following this line of thought, the production of short chain fatty acids (SCFA) such as butyrate has been proposed to protect against different illnesses (Table 2).

b) Probiotics to restore dysbiosis

As we have seen before, dysbiosis are involved in a great variety of different illnesses. Considering this fact, the administration of beneficial microorganisms to restore the normal ecosystem is a strategy to improve the health status of the patient and/or to prevent a normal healthy individual from acquiring

Table 1 Some examples of disbiosis found in obesity and diabetes

\begin{tabular}{|c|c|c|c|c|c|c|}
\hline Disease & Disbiosis & Model & Technique & Sample & $\mathbf{N}$ & Reference \\
\hline \multirow{6}{*}{ Obesity } & $\downarrow$ Bacteroidetes & \multirow{2}{*}{ Mice C57BL/6J } & \multirow{2}{*}{ 16S RNA sequencing } & \multirow{3}{*}{$\begin{array}{l}\text { Distal intestinal } \\
\text { content }\end{array}$} & 5088 & \multirow{2}{*}[39]{} \\
\hline & $\uparrow$ Firmicutes & & & & sequences & \\
\hline & $\uparrow$ Firmicutes & \multirow{3}{*}{ Humans } & 16S RNA sequencing & & 12 & {$[40]$} \\
\hline & \multirow{2}{*}{$\uparrow$ Bacteroidetes } & & Real time PCR & \multirow[t]{2}{*}{ Faecal } & 40 & {$[41]$} \\
\hline & & & 16S RNA sequencing & & 154 & {$[42]$} \\
\hline & $\begin{array}{l}\uparrow \mathrm{H} 2 \text {-producing bacterial groups } \\
\text { (Prevotellaceae family and certain } \\
\text { groups of Firmicutes) }\end{array}$ & Humans & 16S RNA sequencing & Faecal & 9 & {$[43]$} \\
\hline $\begin{array}{l}\text { Type } 1 \\
\text { diabetes }\end{array}$ & $\begin{array}{l}\text { Ratio bacteriodietes/firmicutes } \\
\text { altered }\end{array}$ & $\begin{array}{l}\text { Non obese diabetic } \\
\text { mice (NOD) }\end{array}$ & 16S RNA sequencing & Faecal & & {$[44]$} \\
\hline \multirow{4}{*}{$\begin{array}{l}\text { Type } 2 \\
\text { diabetes }\end{array}$} & $\downarrow$ Prevotella, & \multirow{4}{*}{ Humans } & 16S RNA sequencing Real time PCR & & \multirow[t]{2}{*}{36} & \multirow[t]{2}{*}[45]{} \\
\hline & $\downarrow$ Bitidobacterium spp & & \multirow{3}{*}{$\begin{array}{l}\text { 16S RNA sequencing Real time } \\
\text { PCR DGGE }\end{array}$} & \multirow[t]{3}{*}{ Faecal } & & \\
\hline & $\downarrow$ F. prausnitzii & & & & \multirow[t]{2}{*}{28} & \multirow[t]{2}{*}[46]{} \\
\hline & $\uparrow$ Bacteroides & & & & & \\
\hline
\end{tabular}


Table 2 Benefical effects of short chain fatty accids (SCFA)

\begin{tabular}{|c|c|c|c|}
\hline SCFA & Model & Effect & Reference \\
\hline \multirow[t]{4}{*}{ Butyrate } & Tumorigenesis in rat colon and Human colonic cells & $\begin{array}{l}\text { Inhibit the genotoxic activity of nitrosamides } \\
\text { and hydrogen peroxide }\end{array}$ & {$[47]$} \\
\hline & $\begin{array}{c}\text { Human adenocarcinoma R6/C2 and AA/C1 cells and } \\
\text { carcionoma PC/JW/F1 cells }\end{array}$ & Induce apoptosis & [48] \\
\hline & $\begin{array}{l}\text { Human intestinal primary epithelial cells (HIPEC), HT-29 } \\
\text { and Caco-2 cells }\end{array}$ & Immunoregulatory effects & [49] \\
\hline & Humans with distal ulcerative colitis & Improves UC symthoms & {$[50]$} \\
\hline Butyrate/acetate/propionate & Humans with diversion colitis & $\begin{array}{l}\text { Improves the macroscopic and histological } \\
\text { signs of inflammation }\end{array}$ & [51] \\
\hline \multirow[t]{2}{*}{ Propionate } & HT-29 cells & Anti-proliferative effects & [52] \\
\hline & Madin-Darby bovine kidney epithelial cells (MDBK) & & [53] \\
\hline Acetate & E. coli $\mathrm{O} 157: \mathrm{H} 7$ infection & Protection & [54] \\
\hline
\end{tabular}

dysbiosis in the future. Currently, there is evidence of the use of probiotics as therapeutics against traveler's diarrhea, irritable bowel syndrome (IBS), IBD, lactose intolerance, peptic ulcers, allergy and autoimmune disorders among others [55-60]. For instance, it has been suggested that colonization of the GIT with Bifidobacteria properly shapes gut microbiota, induces oral tolerance and decreases the frequency of allergic disorders [61]. For lactobacilli, a clinical study demonstrates that perinatal administration of a probiotic strain of Lactobacillus rhamnosus GG (LGG) reduces the development of atopic eczema in children [61-64]. This effect may be due to the anti-inflammatory properties of this probiotic bacterium. Consumption of LGG by children with atopic dermatitis has been reported to enhance the production of the anti-inflammatory cytokine IL-10 [65]. Other studies have demonstrated that oral administration of $L$. casei Shirota strain to mice inhibited specific IgE production [66] while Abrahamsson et al. [67] have observed in a double-blind, randomized, placebocontrolled trial that infants treated with $L$. reuteri ATCC 55730 strain had less IgE-associated eczema. As mentioned above, when the equilibrium of the microbiota is disturbed, the bacterial ecosystem is thought to contribute to several intestinal diseases such as IBD. In fact, gut microbiota metabolize nutrients, produce vitamins and degrade toxic products (such as: carcinogens, food additives, bile salts, and cholesterol, among others) $[68,69]$, where the importance and interest in modulate microbiota with probiotic products. Results from animal models and human clinical trials have confirmed various therapeutic effects of selected strains of probiotics in IBD [56,70]. For instance, L. casei BL23 strain has shown anti-inflammatory effects in a murine DSSinduced colitis model [71] and some other probiotic strains (eg. VSL\#3, LGG, BIFICO, E. coli Nissle) have shown effects in human patients with pouchitis, UC and CD [72]. Additionally, the modulatory effect of Lactobacillus acidophilus in intestinal pain due to the induction of opioid and cannabinoid receptors has been reported in rats [73]. This fact highlights the use of probiotics in other intestinal disorders such as such as IBS, characterized by chronic abdominal pain, discomfort, bloating and alteration of bowel habits. In this sense, in the last years, many studies confirm the overall positive results of probiotics in human IBS patients using different bacteria such as: Lactobacillus spp., Bifidobacterium and Streptococcus among others [74].

From this perspective, the use of probiotics has been expanded in the last few years, with a great number of probiotic products in our supermarkets and pharmacies. However, the knowledge of their mechanisms of action remains largely unknown.

\section{New prospects of commensal and probiotic bacteria: genetically modified microorganisms}

a) Strategies to deliver therapeutic molecules. Since probiotic therapy is mainly focused on restoring the normal balance of the intestinal ecosystem, we can deduce that the use of commensal bacteria as probiotics is the natural way to get rid of dysbiosis within the GIT. Furthermore, they represent potential live delivery vectors for target compounds (Figure 2). The use of live delivery vectors, such as food-grade $\mathrm{LAB}$, at the mucosal level has been widely described before [75-79]. They are based on the use of recombinant bacteria producing the heterologous molecule of interest in vivo and their use is mainly related to vaccines. This is due to the fact that genetically engineered bacteria or viruses (used as carriers) producing 


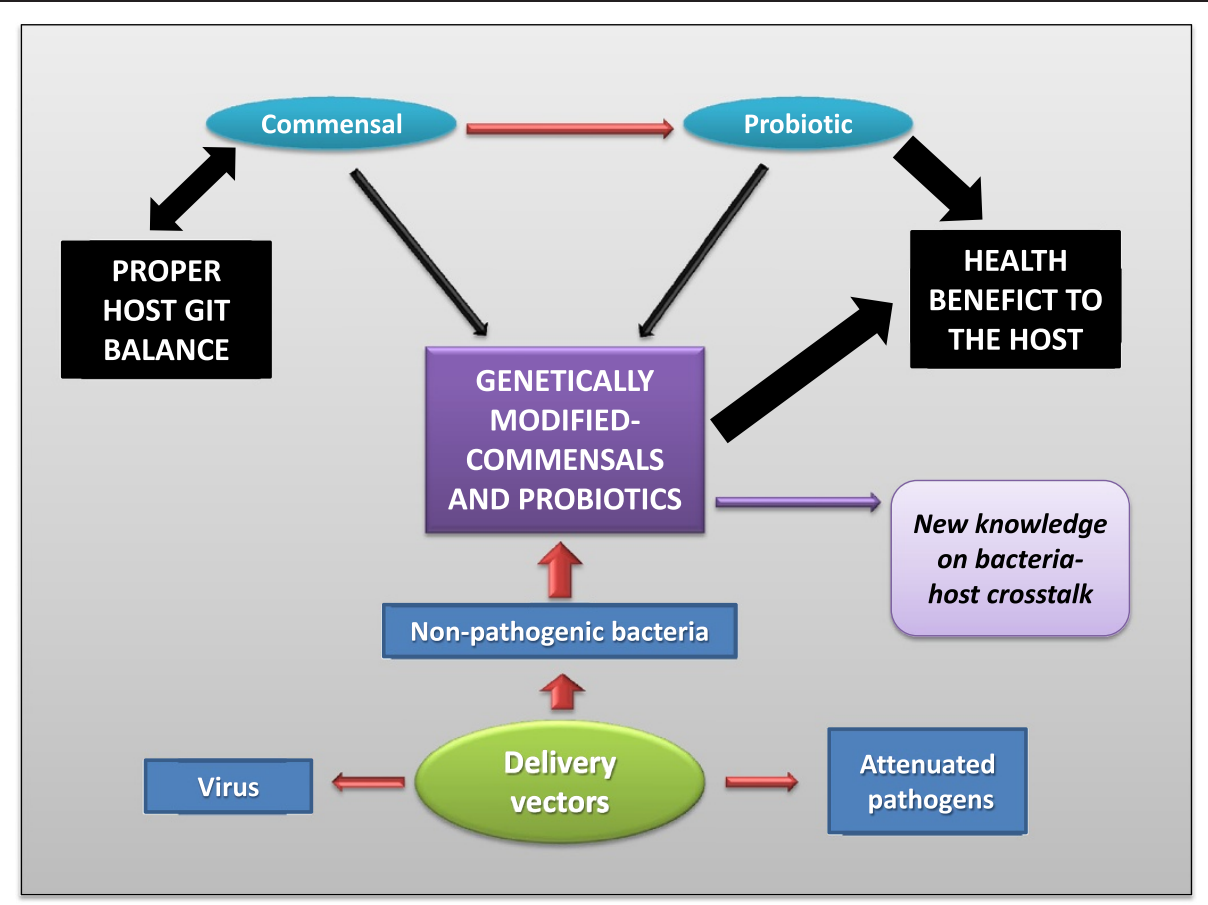

Figure 2 Extension of the commensals-probiotics hypothesis. The development of a genetically modified commensal (or probiotic) could reach all the beneficial properties found in a commensal bacterium joint to the probiotic effects due to the ability to deliver molecules to the gastrointestinal tract (GIT).

heterologous antigens can increase the immunogenicity of otherwise weakly immunogenic antigens. In addition, such live bacterial vectors have the additional advantage (compared to viruses) of having a genome able to harbor many heterologous genes, in contrast to viruses where the capacity to encapsulate foreign DNA is limited. This research field comes from exploring novel effective strategies to deliver therapeutic molecules to the mucosal tissues in order to avoid degradation and promote uptake of the antigen in situ (ie. in the GIT), and stimulate adaptive immune responses rather than the tolerogenic immune responses that are observed in feeding studies with soluble antigens [80]. Besides the enhancement of the potency and specificity of mucosal delivery of therapeutic molecules, the use of mucosal routes reduces potential side effects observed in systemic ones.

In principle, two types of bacterial vectors can be used to deliver compounds at the mucosal level: attenuated pathogens and non-pathogenic bacteria. Gram-positive commensal or food-grade bacteria constitute attractive good alternatives to pathogenic bacteria $[79,81]$. Particularly, the food-grade LAB are attractive candidates because they have been used for centuries in the fermentation and preservation of food, and are considered to be safe organisms with a GRAS (Generally Recognized As Safe) status. One major advantage of LAB as delivery vectors for vaccines purposes is their potential to elicit both antigen-specific immune responses at mucosal surfaces and effective systemic immune responses. Indeed, some studies have successfully shown that candidate $L A B$ vaccines elicited antigen-specific IgA responses in feces, saliva or bronchoalveolar and intestinal lavage fluids, as well as antigen-specific IgA-secreting cells in the lungs and mesenteric lymph nodes [82-94].

These studies with encouraging results confirm the potential use of $\mathrm{LAB}$ as live vectors for mucosal immunization and/or therapy. In this context, the model LAB species, Lactococcus lactis, has been used for the heterologous expression of therapeutic proteins such as: antigens, cytokines and enzymes. Thus, the resulting recombinant lactococci strains have been successfully tested for their prophylactic and therapeutic effects in many animal models such as: Human Papillomavirus type-16 (HPV-16)-induced tumors in mice [83,88], bovine $\beta$-lactoglobulin (BLG)-allergic reaction in mice $[95,96]$ and body weight and food consumption in obese mice $[85,97]$.

b) Use of recombinant LAB and commensals in IBD. Modulation of the mucosal immune system has been demonstrated in IBD. The currently used therapies to treat IBD are based on 
anti-inflammatory drugs combined with immunosuppressives [98]. Immunomodulatory molecules have been efficient in the control of inflammation and in the remission of the episodes of the illness. The use of LAB to prevent and treat colitis was performed with a recombinant $L$. lactis strain producing and delivering IL-10, an anti-inflammatory cytokine, in situ in different mouse models [99]. Daily mucosal administration of recombinant $L$. lactis secreting IL-10 led to a 50\% decrease of the colitis induced by the administration of dextran sodium sulfate (DSS) in mice. This beneficial effect was dependent on the in situ secretion of IL-10 by the live lactococci. The rationale in using recombinant $L$. lactis for a local delivery of IL-10 in IBD is due to the large number of scientific studies proving that the topical treatment with this cytokine has clinic benefits [100] although systemic IL-10 administration in Crohn's disease patients has been associated with considerable side effects which are partly due to the fact that systemic IL-10 induces the proinflammatory cytokine IFN- $\gamma$ [101-103]. To address the safety issues in using genetically modified organisms in humans, the gene encoding the $L$. lactis thymidylate synthase (thy $A$ ) was replaced by the gene of the human IL-10 (hIL-10) to generate one L. lactis strain auxotrophic for thymidine or thymine [104]. The viability and contention of this strain was validated in vivo in a swine model [104]. Additionally, a small Phase I clinical study in patients with CD using the thyA-/hIL-10+ strain was recently conducted. This study not only showed that the contention strategy is effective, but also that the mucosal expression of IL-10 by L. lactis is feasible in humans [105]. However, a phase IIA trial was performed which revealed that, although safety, tolerability, environmental containment and assessment of biomarkers associated with the strains have been achieved, no statistically significant difference has been found versus placebo in terms of beneficial effects (press release published in 2009). Due to these results, the necessity to optimize the LAB delivery strategy (new strains, different expression systems and different nature of the delivered molecules) is a requirement to reach a clear demonstration of their efficacy in human clinical trials, leading to their better acceptance [76-78,106-109]. The delivery of immunosuppressive cytokines by other bacteria has also been tested. The probiotic potential of IL-10-expressing E. coli Nissle 1917 has been outlined in a mouse model of IBD [110]. The use of LAB to produce Trefoil Factors (TFF) at the mucosal level to treat IBD has also been studied. TFF are a class of nonmitogenic peptides that play important roles in the protection and repair of the intestinal epithelium [111]. These peptides are known because of their strong protective effects and for repairing the mucosa after damage. For this reason, they are interesting molecules to potentially treat IBD. However, when they are administered by an oral route, they adhere to the gut mucosa and are absorbed at the intestinal level. Interestingly, intragastric administration of recombinant $L$. lactis secreting TFF leads to the expression of the active peptides in the colon and prevents and repairs the damage due to the acute colitis induced by DSS [112]. Another strategy to treat colitis was also based on the use of recombinant L. lactis secreting the LcrV antigen, an anti-inflammatory protein produced by Yersinia pseudotuberculosis to escape the immune response of the host. The therapeutic and protective potential of this strain was evaluated using two colitis murine models: DSS and trinitrobenzene sulfonic acid (TNBS) [113]. Still, another strategy to treat IBD is the use of antioxidant enzymes. It is well established that GIT inflammation is associated with an influx of neutrophils and macrophages and with the production of inflammatory mediators such as: proteases, cytokines and reactive oxygen species (ROS) [114]. ROS include the superoxide radical $\left(\mathrm{O}_{2}{ }^{\circ}-\right)$, hydrogen peroxide $\left(\mathrm{H}_{2} \mathrm{O}_{2}\right)$, and the hydroxyl radical $(\cdot \mathrm{OH})$. Their reactivity toward lipids, proteins and DNA causes both cytotoxic and mutagenic cellular damages [115]. To detoxify ROS, cells have evolved protective mechanisms via antioxidant enzymes such as superoxide dismutases (SOD) and catalases (CAT) which degrade $\mathrm{O}_{2}{ }^{\circ-}$ and $\mathrm{H}_{2} \mathrm{O}_{2}$ respectively, and thus prevent the formation of. $\mathrm{OH}$ [116]. In this context, different studies have shown that recombinant strains of Lactobacillus spp. expressing either SOD or CAT can reduce inflammation in mouse models [71,117-119]. In some cases, the anti-inflammatory mechanism of these recombinant strains has been elucidated and linked to the inhibition of neutrophil recruitment [117]. The mucosal expression of elafin, a natural protease inhibitor expressed in healthy intestinal mucosa, is diminished in patients with IBD.

Recently, LAB secreting elafin have been tested in chronic and acute colitis models and the inflamed epithelium was protected from increased intestinal permeability and from the release of cytokines and chemokines by LAB secreting elafin [120].

In addition to these recombinant probiotic strains, mutants in specific genes encoding potential probiotic functions (mucal adhesion factors, 
resistance to acid, specific cell wall components, etc.) have been engineered to compare their biological effects with that of their wild-type counterparts. In 2005, Grangette et al. [121] has provided an illustration of this approach by constructing a mutant of Lactobacillus plantarum impaired in its capacity to incorporate D-alanine in teichoic acids (Dlt mutant) [121]. Strikingly, when tested in vivo, the Dlt ${ }^{-}$mutant proved to be more protective in a mouse model of colitis than the wildtype strain. Furthermore, the use of lipoteichoic acid (LTA)-deficient L. acidophilus in in vitro analysis enhances IL-10 production by dendritic cells and macrophages and downregulates IL-12 and TNF- $\alpha$ [122]. This strain is also able to significantly protect dextran sulfate sodium and $\mathrm{CD} 4{ }^{+} \mathrm{CD} 45 \mathrm{RB}$ high

T cell-induced colitis in mice [123] and to normalize innate and adaptative pathogenic immune responses in established colonic polyps causing cancer regression [124]. However, no protective effects have been found in LTA-induced pro-inflammatory signals and subsequent colitis [125]. Altogether, with the possibility to express different factors such as ScFv antibodies, host targeting molecules and immunomodulators in LAB, more applications and progress towards studies in humans should be performed in a next future.

The next step in this field seems to choose new delivery bacteria. As mentioned above, L. lactis is the most widely used LAB in the production of heterologous proteins and is considered as the model LAB and live delivery vector model [75]. Despite all the advantages mentioned above, this bacterium has a short survival time ( 24 hours) in the human GIT leading thus to a reduced time of action. In contrast, other probiotic bacteria which could be natural colonizers of the GIT, could combine their intrinsic probiotic effects to the probiotic effects conferred by the heterologous delivered protein. The most achieved project in this field is the one based on the use of the commensal Bacteroides ovatus [126] Indeed, Hamady et al. [127] chose this bacterium for the in vivo delivery of proteins for its ability to colonize the colon and its xylan utilisation properties. They were able to develop a xylan-regulated delivery of i) human keratynocyte growth factor-2 to the inflamed colon [128] and ii) the human TGF-b1 to treat colitis in mice [129]. These promising results confirm the potential of the use of recombinant commensal for in vivo delivery.

\section{Conclusions and future research}

We can conclude that current probiotic research encourages the search and characterization of gut bacteria as a model for finding new natural or engineered probiotic strains to be used to restore the normal balance of the human gut ecosystem.

The fact that commensal and probiotic bacteria interact with the host immune system is now well accepted and illustrated by in vitro and in vivo experiments. However, the current knowledge of the molecular mechanisms involved in this cross-talk remain poorly understood. Although some mechanisms and active compounds have been identified in a few commensal or probiotic strains [130], and taking into account that the human GIT is composed of $10^{13}-10^{14}$ microorganisms, it is necessary to explore profoundly this research area and in particular to elucidate the exact role of bacterial compounds in homeostasis and immune response.

As for the use of genetically modified commensal and probiotic bacteria in humans, it is certain that most of the studies being done are Proof-of-Concept. However, although some researchers have claimed that genetically modified probiotics should be banned [131], the data obtained in the phase I clinical trial with the recombinant strain of L. lactis secreting IL-10 (see above in the text) showed that the containment strategy (ie. release of such genetically modified organisms into nature) used to construct the strain [104] was not only safe and effective but also that mucosal delivery of IL10 by a genetically modified LAB is feasible in humans [105].

In conclusion, it is clear that the analysis of the impact of commensals and probiotics on the host immune system has entered a new and fascinating phase of research. This new area offers us new knowledge that can be exploited to develop new approaches to modulate host immunity for protection against infectious diseases or for immunotherapy.

\section{Abbreviations}

BLG: $\beta$-lactoglobulin; CAT: Catalases; CD: Crohn's disease; DSS: Dextran sodium sulfate; GIT: Gastrointestinal tract; GMO: Genetically modified organisms; GRAS: Generally recognized as safe; HPV-16: Human Papillomavirus type-16; IBD: Inflammatory bowel disease; IBS: Irritable bowel syndrome; LAB: Lactic acid bacteria; LGG: Lactobacillus rhamnosus GG; ROS: Reactive oxygen species; SCFA: Short chain fatty acids; SOD: Superoxide dismutases; TFF: Treefoil factors; TNBS: Trinitrobenzene sulfonic acid; UC: Ulcerative colitis.

\section{Competing interests}

The authors declare that they have no competing interests.

\section{Authors' contribution}

RM and LBH wrote the main text, figures and tables. SM, NK, JU, PL corrected and helped to draft the manuscript. All authors have read and approved the final manuscript.

\section{Acknowledgements}

RM and SM receive a salary from FParis collaborative project selected and supported by the Vitagora Competitive Cluster and funded by the French FUI (Fond Unique Interministériel; FUI: nF1010012D), the FEDER (Fonds Européen de Développement Régional; Bourgogne: 34606), the Burgundy Region, the Conseil Général 21 and the Grand Dijon. 
Received: 14 May 2013 Accepted: 18 July 2013

Published: 23 July 2013

\section{References}

1. Hooper LV, Gordon J: Commensal host-bacterial relationships in the gut. Science 2001, 292:1115-1118.

2. Sekirov I, Russell SL, Antunes LC, Finlay BB: Gut microbiota in health and disease. Physiol Rev 2010, 90:859-904.

3. Frank DN, St Amand AL, Feldman RA, Boedeker EC, Harpaz N, Pace NR: Molecular-phylogenetic characterization of microbial community imbalances in human inflammatory bowel diseases. Proc Natl Acad Sci USA 2007, 104:13780-13785.

4. Qin JJ, Li RQ, Raes J, Arumugam M, Burgdorf KS, Manichanh C, Nielsen T, Pons N, Levenez F, Yamada T, et al: A human gut microbial gene catalogue established by metagenomic sequencing. Nature 2010, 464:59-U70.

5. Leser TD, Molbak L: Better living through microbial action: the benefits of the mammalian gastrointestinal microbiota on the host. Environ Microbiol 2009, 11:2194-2206.

6. Lepage P, Seksik P, Sutren M, de la Cochetiere MF, Jian R, Marteau P, Dore J: Biodiversity of the mucosa-associated microbiota is stable along the distal digestive tract in healthy individuals and patients with IBD. Inflammatory Bowel Diseases 2005, 11:473-480.

7. van der Waaij LA, Harmsen HJ, Madjipour M, Kroese FG, Zwiers M, van Dullemen HM, de Boer NK, Welling GW, Jansen PL: Bacterial population analysis of human colon and terminal ileum biopsies with 16S rRNAbased fluorescent probes: commensal bacteria live in suspension and have no direct contact with epithelial cells. Inflamm Bowel Dis 2005, 11:865-871

8. Zoetendal EG, von Wright A, Vilpponen-Salmela T, Ben-Amor K, Akkermans ADL, de Vos WM: Mucosa-associated bacteria in the human gastrointestinal tract are uniformly distributed along the colon and differ from the community recovered from feces. Appl Environ Microbiol 2002, 68:3401-3407.

9. Swidsinski A, Loening-Baucke V, Lochs H, Hale LP: Spatial organization of bacterial flora in normal and inflamed intestine: a fluorescence in situ hybridization study in mice. World I Gastroenterol 2005, 11:1131-1140.

10. Tannock GW: A special fondness for lactobacilli. Appl Environ Microbiol 2004, 70:3189-3194

11. Mazmanian SK, Liu CH, Tzianabos AO, Kasper DL: An immunomodulatory molecule of symbiotic bacteria directs maturation of the host immune system. Cell 2005, 122:107-118.

12. Mandar R, Mikelsaar M: Transmission of mother's microflora to the newborn at birth. Biology of the Neonate 1996, 69:30-35.

13. Spor A, Koren O, Ley R: Unravelling the effects of the environment and host genotype on the gut microbiome. Nat Rev Microbiol 2011, 9:279-290.

14. Food and Agriculture Organization: FAONHO Working Group report on drafting guidelines for the evaluation of probiotics in food. London, United Kingdom: Food and Agriculture Organization; 2002:p 11.

15. Metchnikoff E: Essais optimistes. In The prolongation of life. Optimistic studies. Translated and edited by P. Chalmers Mitchell. London: Heinemann; 1907.

16. de Vrese M, Schrezenmeir J: Probiotics, prebiotics, and synbiotics. Adv Biochem Eng Biotechnol 2008, 111:1-66.

17. Gareau MG, Sherman PM, Walker WA: Probiotics and the gut microbiota in intestinal health and disease. Nat Rev Gastroenterol Hepatol 2010, 7:503-514.

18. Besselink MG, van Santvoort HC, Buskens E, Boermeester MA, van Goor H, Timmerman HM, Nieuwenhuijs VB, Bollen TL, van Ramshorst B, Witteman BJ, et al: Probiotic prophylaxis in predicted severe acute pancreatitis: a randomised, double-blind, placebo-controlled trial. Lancet 2008, 371:651-659.

19. Pineiro $M$, Stanton C: Probiotic bacteria: legislative framework requirements to evidence basis. J Nutr 2007, 137:850s-853s.

20. Kechaou N, Chain F, Gratadoux JJ, Blugeon S, Bertho N, Chevalier C, Le Goffic R, Courau S, Molimard P, Chatel JM, et al: Identification of one novel candidate probiotic Lactobacillus plantarum strain active against influenza virus infection in mice by a large-scale screening. Appl Environ Microbiol 2013, 79:1491-1499.

21. Marteau P: Living drugs for gastrointestinal diseases: the case for probiotics. Dig Dis 2006, 24:137-147.

22. Sokol H, Pigneur B, Watterlot L, Lakhdari O, Bermudez-Humaran LG, Gratadoux JJ, Blugeon S, Bridonneau C, Furet JP, Corthier G, et al: Faecalibacterium prausnitzii is an anti-inflammatory commensal bacterium identified by gut microbiota analysis of Crohn disease patients. Proc Natl Acad Sci USA 2008, 105:16731-16736.

23. Miquel S, Martin R, Rossi O, Bermudez-Humaran L, Chatel J, Sokol H, Thomas M, Wells J, Langella P: Faecalibacterium prausnitzii and human intestinal health. Curr Opin Microbiol 2013.

24. Hampe J, Franke A, Rosenstiel P, Till A, Teuber M, Huse K, Albrecht M, Mayr G, De La Vega FM, Briggs J, et al: A genome-wide association scan of nonsynonymous SNPs identifies a susceptibility variant for Crohn disease in ATG16L1. Nat Genet 2007, 39:207-211.

25. Hugot JP, Chamaillard M, Zouali H, Lesage S, Cezard JP, Belaiche J, Almer S, Tysk C, O'Morain CA, Gassull M, et al: Association of NOD2 leucine-rich repeat variants with susceptibility to Crohn's disease. Nature 2001, 411:599-603.

26. Bamias G, Nyce MR, De La Rue SA, Cominelli F, American College of $P$, American Physiological S: New concepts in the pathophysiology of inflammatory bowel disease. Ann Intern Med 2005, 143:895-904.

27. Shanahan F: Host-flora interactions in inflammatory bowel disease. Inflamm Bowel Dis 2004, 10(Suppl 1):S16-S24.

28. Danese S, Sans M, Fiocchi C: Inflammatory bowel disease: the role of environmental factors. Autoimmun Rev 2004, 3:394-400.

29. Chiodini RJ, Vankruiningen HJ, Thayer WR, Merkal RS, Coutu JA: Possible Role of Mycobacteria in Inflammatory Bowel-Disease.1. An Unclassified Mycobacterium Species Isolated from Patients with Crohns-Disease. Dig Dis Sci 1984, 29:1073-1079.

30. Darfeuille-Michaud A, Boudeau J, Bulois P, Neut C, Glasser AL, Barnich N, Bringer MA, Swidsinski A, Beaugerie L, Colombel JF: High prevalence of adherent-invasive Escherichia coli associated with ileal mucosa in Crohn's disease. Gastroenterology 2004, 127:412-421.

31. Sokol H, Lay C, Seksik P, Tannock GW: Analysis of bacterial bowel communities of IBD patients: what has it revealed? Inflamm Bowel Dis 2008, 14:858-867.

32. Swidsinski A, Loening-Baucke V, Vaneechoutte M, Doerffel Y: Active Crohn's disease and ulcerative colitis can be specifically diagnosed and monitored based on the biostructure of the fecal flora. Inflammatory Bowel Diseases 2008, 14:147-161.

33. Jia WJ, Whitehead RN, Griffiths L, Dawson C, Waring RH, Ramsden DB, Hunter JO, Cole JA: Is the abundance of Faecalibacterium prausnitzi relevant to Crohn's disease? FEMS Microbiol Lett 2010, 310:138-144.

34. Delzenne NM, Cani PD: Interaction between obesity and the Gut microbiota: relevance in nutrition. Annu Rev Nutr 2011, 31:15-31.

35. Musso G, Gambino R, Cassader M: Obesity, diabetes, and gut microbiota the hygiene hypothesis expanded? Diabetes Care 2010, 33:2277-2284.

36. Strachan DP: Hay-fever, hygiene, and household size. British Medical Journal 1989, 299:1259-1260.

37. Umetsu DT, McIntire JJ, Akbari O, Macaubas C, Dekruyff RH: Asthma: an epidemic of dysregulated immunity. Nat Immunol 2002, 3:715-720.

38. Von Hertzen LC, Haahtela T: Asthma and atopy - the price of affluence? Allergy 2004, 59:124-137.

39. Ley RE, Backhed F, Turnbaugh P, Lozupone CA, Knight RD, Gordon Jl: Obesity alters gut microbial ecology. Proc Natl Acad Sci USA 2005, 102:11070-11075.

40. Armougom F, Henry M, Vialettes B, Raccah D, Raoult D: Monitoring bacterial community of human gut microbiota reveals an increase in Lactobacillus in obese patients and Methanogens in anorexic patients. PLoS One 2009, 4:e7125.

41. Ley RE, Turnbaugh PJ, Klein S, Gordon Jl: Microbial ecology - human gut microbes associated with obesity. Nature 2006, 444:1022-1023.

42. Turnbaugh PJ, Hamady M, Yatsunenko T, Cantarel BL, Duncan A, Ley RE, Sogin ML, Jones WJ, Roe BA, Affourtit JP, et al: A core gut microbiome in obese and lean twins. Nature 2009, 457:480-484.

43. Zhang HS, DiBaise JK, Zuccolo A, Kudrna D, Braidotti M, Yu YS, Parameswaran P, Crowell MD, Wing R, Rittmann BE, Krajmalnik-Brown R: Human gut microbiota in obesity and after gastric bypass. Proc Natl Acad Sci USA 2009, 106:2365-2370.

44. Wen L, Ley RE, Volchkov PY, Stranges PB, Avanesyan L, Stonebraker AC, Hu $\mathrm{CY}$, Wong FS, Szot GL, Bluestone JA, et al: Innate immunity and intestinal microbiota in the development of Type 1 diabetes. Nature 2008, 455:1109-U1110.

45. Larsen N, Vogensen FK, van den Berg FW, Nielsen DS, Andreasen AS, Pedersen BK, Al-Soud WA, Sørensen SJ, Hansen LH, Jakobsen M: Gut microbiota in human adults with type 2 diabetes differs from non- 
diabetic adults. PLoS One 2010, 5(2):e9085. doi:10.1371/journal. pone.0009085. PubMed PMID: 20140211; PubMed Central PMCID: PMC2816710.

46. Wu XK, Ma CF, Han L, Nawaz M, Gao F, Zhang XY, Yu PB, Zhao CA, Li LC, Zhou AP, et al: Molecular Characterisation of the Faecal Microbiota in Patients with Type II Diabetes. Curr Microbiol 2010, 61:69-78.

47. Wollowski I, Rechkemmer G, Pool-Zobel BL: Protective role of probiotics and prebiotics in colon cancer. Am J Clin Nutr 2001, 73:451s-455s.

48. Hague A, Manning AM, Hanlon KA, Huschtscha LI, Hart D, Paraskeva C: Sodium butyrate induces apoptosis in human colonic tumour cell lines in a p53-independent pathway: implications for the possible role of dietary fibre in the prevention of large-bowel cancer. Int J Cancer 1993, 55:498-505.

49. Bocker U, Nebe T, Herweck F, Holt L, Panja A, Jobin C, Rossol S, BS R, Singer MV: Butyrate modulates intestinal epithelial cell-mediated neutrophil migration. Clin Exp Immunol 2003, 131:53-60.

50. Luhrs H, Gerke T, Muller JG, Melcher R, Schauber J, Boxberger F, Scheppach W, Menzel T: Butyrate inhibits NF-kappa B activation in lamina propria macrophages of patients with ulcerative colitis. Scand J Gastroenterol 2002, 37:458-466.

51. Harig JM, Soergel KH, Komorowski RA, Wood CM: Treatment of diversion colitis with short-chain-fatty acid irrigation. N Engl J Med 1989, 320:23-28.

52. Jan G, Belzacq AS, Haouzi D, Rouault A, Metivier D, Kroemer G, Brenner C: Propionibacteria induce apoptosis of colorectal carcinoma cells via short-chain fatty acids acting on mitochondria. Cell Death Differ 2002, 9:179-188.

53. Li CJ, Elsasser TH: Butyrate-induced apoptosis and cell cycle arrest in bovine kidney epithelial cells: Involvement of caspase and proteasome pathways. J Anim Sci 2005, 83:89-97.

54. Fukuda S, Toh H, Hase K, Oshima K, Nakanishi Y, Yoshimura K, Tobe T, Clarke $J M$, Topping DL, Suzuki T, et al: Bifidobacteria can protect from enteropathogenic infection through production of acetate. Nature 2011, 469:543-U791.

55. Masood MI, Qadir MI, Shirazi JH, Khan IU: Beneficial effects of lactic acid bacteria on human beings. Crit Rev Microbiol 2011, 37:91-98.

56. Gionchetti $P$, Amadini C, Rizzello F, Venturi A, Poggioli G, Campieri M: Probiotics for the treatment of postoperative complications following intestinal surgery. Best Pract Res Clin Gastroenterol 2003, 17:821-831.

57. McCarthy J, O'Mahony L, O'Callaghan L, Sheil B, Vaughan EE, Fitzsimons N Fitzgibbon J, O'Sullivan GC, Kiely B, Collins JK, Shanahan F: Double blind, placebo controlled trial of two probiotic strains in interleukin 10 knockout mice and mechanistic link with cytokine balance. Gut 2003, 52:975-980

58. Savilahti E, Kuitunen M, Vaarala O: Pre and probiotics in the prevention and treatment of food allergy. Current Opinion in Allergy and Clinical Immunology 2008, 8:243-248.

59. Vliagoftis $\mathrm{H}$, Kouranos VD, Betsi Gl, Falagas ME: Probiotics for the treatment of allergic rhinitis and asthma: systematic review of randomized controlled trials. Ann Allergy Asthma Immunol 2008, 101:570-579.

60. Weston S, Halbert A, Richmond P, Prescott SL: Effects of probiotics on atopic dermatitis: a randomised controlled trial. Arch Dis Child 2005, 90:892-897.

61. Isolauri E, Rautava S, Salminen S: Probiotics in the development and treatment of allergic disease. Gastroenterol Clin North Am 2012, 41:747-762.

62. Nermes M, Kantele JM, Atosuo TJ, Salminen S, Isolauri E: Interaction of orally administered Lactobacillus rhamnosus GG with skin and gut microbiota and humoral immunity in infants with atopic dermatitis. Clinical and Experimental Allergy 2011, 41:370-377.

63. Kuitunen M: Probiotics and prebiotics in preventing food allergy and eczema. Curr Opin Allergy Clin Immunol 2013, 13:280-286.

64. Foolad N, Brezinski EA, Chase EP, Armstrong AW: Effect of nutrient supplementation on atopic dermatitis in children: a systematic review of probiotics, prebiotics, formula, and fatty acids. JAMA Dermatol 2013, 149:350-355.

65. Pessi T, Sutas $Y$, Hurme H, Isolauri E: Interleukin-10 generation in atopic children following oral Lactobacillus rhamnosus GG. Clinical and Experimental Allergy 2000, 30:1804-1808.

66. Lim LH, Li HY, Huang CH, Lee BW, Lee YK, Chua KY: The Effects of HeatKilled Wild-Type Lactobacillus casei Shirota on Allergic Immune Responses in an Allergy Mouse Model. International Archives of Allergy and Immunology 2009, 148:297-304.
67. Abrahamsson TR, Jakobsson T, Bottcher MF, Fredrikson M, Jenmalm MC, Bjorksten B, Oldaeus G: Probiotics in prevention of IgE-associated eczema: a double-blind, randomized, placebo-controlled trial. J Allergy Clin Immunol 2007, 119:1174-1180.

68. Knight DJ, Girling KJ: Gut flora in health and disease. Lancet 1831, 2003:361

69. Heselmans M, Reid G, Akkermans LM, Savelkoul H, Timmerman H, Rombouts FM: Gut flora in health and disease: potential role of probiotics. Curr Issues Intest Microbiol 2005, 6:1-7.

70. Kruis W: Review article: antibiotics and probiotics in inflammatory bowel disease. Aliment Pharmacol Ther 2004, 20:75-78.

71. Rochat T, Bermudez-Humaran L, Gratadoux JJ, Fourage C, Hoebler C, Corthier G, Langella P: Anti-inflammatory effects of Lactobacillus casei BL23 producing or not a manganese-dependant catalase on DSSinduced colitis in mice. Microb Cell Fact 2007, 6:22.

72. Hormannsperger G, Haller D: Molecular crosstalk of probiotic bacteria with the intestinal immune system: clinical relevance in the context of inflammatory bowel disease. Int J Med Microbiol 2010, 300:63-73.

73. Rousseaux C, Thuru X, Gelot A, Barnich N, Neut C, Dubuquoy L, Dubuquoy C, Merour E, Geboes K, Chamaillard M, et al: Lactobacillus acidophilus modulates intestinal pain and induces opioid and cannabinoid receptors. Nature Medicine 2007, 13:35-37.

74. Haller D, Antoine JM, Bengmark S, Enck P, Rijkers GT, Lenoir-Wijnkoop I: Guidance for substantiating the evidence for beneficial effects of probiotics: probiotics in chronic inflammatory bowel disease and the functional disorder irritable bowel syndrome. J Nutr 2010, 140:690S-697S.

75. Bermudez-Humaran LG: Lactococcus lactis as a live vector for mucosal delivery of therapeutic proteins. Hum Vaccin 2009, 5:264-267.

76. Bermudez-Humaran LG, Kharrat P, Chatel JM, Langella P: Lactococci and lactobacilli as mucosal delivery vectors for therapeutic proteins and DNA vaccines. Microb Cell Fact 2011, 10(Suppl 1):S4

77. Bermúdez-Humarán LG, Aubry C, Motta JP, Deraison C, Steidler L, Vergnolle N, Chatel JM, Langella P: Engineering lactococci and lactobacilli for human health. Curr Opin Microbiol 2013, S1369-5274(13):00076-3. doi:10.1016/j.mib.2013.06.002. [Epub ahead of print] PubMed PMID: 23850097

78. Wells JM, Mercenier A: Mucosal delivery of therapeutic and prophylactic molecules using lactic acid bacteria. Nat Rev Microbiol 2008, 6:349-362.

79. Seegers JFML: Lactobacilli as live vaccine delivery vectors: progress and prospects. Trends Biotechnol 2002, 20:508-515.

80. Neutra MR, Kozlowski PA: Mucosal vaccines: the promise and the challenge. Nat Rev Immunol 2006, 6:148-158.

81. Lee SF: Oral colonization and immune responses to Streptococcus gordonii: potential use as a vector to induce antibodies against respiratory pathogens. Curr Opin Infect Dis 2003, 16:231-235.

82. Bermudez-Humaran LG, Cortes-Perez NG, Le Loir Y, Alcocer-Gonzalez JM, Tamez-Guerra RS, de Oca-Luna RM, Langella P: An inducible surface presentation system improves cellular immunity against human papillomavirus type 16 E7 antigen in mice after nasal administration with recombinant lactococci. J Med Microbiol 2004, 53:427-433

83. Bermudez-Humaran LG, Cortes-Perez NG, Lefevre F, Guimaraes V, Rabot S, Alcocer-Gonzalez JM, Gratadoux JJ, Rodriquez-Padilla C, Tamez-Guerra RS, Corthier G, et al: A novel mucosal vaccine based on live Lactococci expressing E7 antigen and IL-12 induces systemic and mucosal immune responses and protects mice against human papillomavirus type 16induced tumors. J Immunol 2005, 175:7297-7302.

84. Bermudez-Humaran LG, Langella P, Cortes-Perez NG, Gruss A, Tamez-Guerra RS, Oliveira SC, Saucedo-Cardenas O, Montes de Oca-Luna R, Le Loir Y: Intranasal immunization with recombinant Lactococcus lactis secreting murine interleukin-12 enhances antigen-specific Th1 cytokine production. Infect Immun 2003, 71:1887-1896.

85. Bermudez-Humaran LG, Nouaille S, Zilberfarb V, Corthier G, Gruss A, Langella $P$, Issad T: Effects of intranasal administration of a leptinsecreting Lactococcus lactis recombinant on food intake, body weight, and immune response of mice. Appl Environ Microbiol 2007, 73:5300-5307.

86. Cauchard S, Bermudez-Humaran LG, Blugeon S, Laugier C, Langella P, Cauchard J: Mucosal co-immunization of mice with recombinant lactococci secreting VapA antigen and leptin elicits a protective immune response against Rhodococcus equi infection. Vaccine 2011, 30:95-102. 
87. Cortes-Perez NG, Bermudez-Humaran LG, Le Loir Y, Rodriguez-Padilla C, Gruss A, Saucedo-Cardenas O, Langella P, Montes-de-Oca-Luna R: Mice immunization with live lactococci displaying a surface anchored HPV-16 E7 oncoprotein. FEMS Microbiol Lett 2003, 229:37-42.

88. Cortes-Perez NG, Lefevre F, Corthier G, Adel-Patient K, Langella P, BermudezHumaran LG: Influence of the route of immunization and the nature of the bacterial vector on immunogenicity of mucosal vaccines based on lactic acid bacteria. Vaccine 2007, 25:6581-6588.

89. Corthesy B, Boris S, Isler P, Grangette C, Mercenier A: Oral immunization of mice with lactic acid bacteria producing Helicobacter pylori urease $B$ subunit partially protects against challenge with Helicobacter felis. J Infect Dis 2005, 192:1441-1449.

90. Grangette C, Muller-Alouf H, Hols P, Goudercourt D, Delcour J, Turneer M, Mercenier A: Enhanced mucosal delivery of antigen with cell wall mutants of lactic acid bacteria. Infect Immun 2004, 72:2731-2737.

91. Grangette C, Muller-Alouf H, Geoffroy M, Goudercourt D, Turneer M, Mercenier A: Protection against tetanus toxin after intragastric administration of two recombinant lactic acid bacteria: impact of strain viability and in vivo persistence. Vaccine 2002, 20:3304-3309.

92. Grangette C, Muller-Alouf H, Goudercourt D, Geoffroy MC, Turneer M, Mercenier A: Mucosal immune responses and protection against tetanus toxin after intranasal immunization with recombinant Lactobacillus plantarum. Infect Immun 2001, 69:1547-1553.

93. Wells JM, Wilson PW, Norton PM, Gasson MJ, Le Page RW: Lactococcus lactis: high-level expression of tetanus toxin fragment $C$ and protection against lethal challenge. Mol Microbiol 1993, 8:1155-1162.

94. Robinson K, Chamberlain LM, Schofield KM, Wells JM, Le Page RW: Oral vaccination of mice against tetanus with recombinant Lactococcus lactis. Nat Biotechnol 1997, 15:653-657.

95. Cortes-Perez NG, Ah-Leung S, Bermudez-Humaran LG, Corthier G, Wal JM, Langella P, Adel-Patient K: Intranasal coadministration of live lactococci producing interleukin-12 and a major cow's milk allergen inhibits allergic reaction in mice. Clin Vaccine Immunol 2007, 14:226-233.

96. Cortes-Perez NG, Ah-Leung S, Bermudez-Humaran LG, Corthier G, Langella $P$, Wal JM, Adel-Patient K: Allergy therapy by intranasal administration with recombinant Lactococcus lactis Producing bovine betalactoglobulin. Int Arch Allergy Immunol 2009, 150:25-31.

97. Amar J, Chabo C, Waget A, Klopp P, Vachoux C, Bermudez-Humaran LG, Smirnova N, Berge M, Sulpice T, Lahtinen S, et al: Intestinal mucosal adherence and translocation of commensal bacteria at the early onset of type 2 diabetes: molecular mechanisms and probiotic treatment. EMBO Mol Med 2011, 3:559-572.

98. Kuhbacher T, Folsch UR: Practical guidelines for the treatment of inflammatory bowel disease. World J Gastroenterol 2007, 13:1149-1155.

99. Steidler L, Hans W, Schotte L, Neirynck S, Obermeier F, Falk W, Fiers W, Remaut $E$ : Treatment of murine colitis by Lactococcus lactis secreting interleukin-10. Science 2000, 289:1352-1355.

100. Dumot JA, Conwell DL, Zuccaro G, Vargo JJ, Shay SS, Easley KA, Ponsky JL: A randomized, double blind study of interleukin 10 for the prevention of ERCP-induced pancreatitis. Am J Gastroenterol 2001, 96:2098-2102.

101. Fedorak RN, Gangl A, Elson CO, Rutgeerts P, Schreiber S, Wild G, Hanauer SB, Kilian A, Cohard M, LeBeaut A, Feagan B: Recombinant human interleukin 10 in the treatment of patients with mild to moderately active Crohn's disease. The Interleukin 10 Inflammatory Bowel Disease Cooperative Study Group. Gastroenterology 2000, 119:1473-1482.

102. Targan SR, Hanauer SB, van Deventer SJH, Mayer L, Present DH, Braakman T, DeWoody KL, Schaible TF, Rutgeerts PJ: A short-term study of chimeric monoclonal antibody CA2 to tumor necrosis factor alpha for Crohn's disease. N Engl J Med 1997, 337:1029-1035.

103. Tilg $H$, van Montfrans $C$, van den Ende A, Kaser A, van Deventer SJ, Schreiber S, Gregor M, Ludwiczek O, Rutgeerts P, Gasche C, et al: Treatment of Crohn's disease with recombinant human interleukin 10 induces the proinflammatory cytokine interferon gamma. Gut 2002, 50:191-195.

104. Steidler L, Neirynck S, Huyghebaert N, Snoeck V, Vermeire A, Goddeeris B, Cox E, Remon JP, Remaut E: Biological containment of genetically modified Lactococcus lactis for intestinal delivery of human interleukin 10. Nat Biotechnol 2003, 21:785-789.

105. Braat H, Rottiers P, Hommes DW, Huyghebaert N, Remaut E, Remon JP, van Deventer SJ, Neirynck S, Peppelenbosch MP, Steidler L: A phase I trial with transgenic bacteria expressing interleukin-10 in Crohn's disease. Clin Gastroenterol Hepatol 2006, 4:754-759.
106. Ross JJ, Boucher PE, Bhattacharyya SP, Kopecko DJ, Sutkowski EM, Rohan PJ, Chandler DKF, Vaillancourt J: Considerations in the development of live biotherapeutic products for clinical use. Current Issues in Molecular Biology 2008, 10:13-16.

107. Wells J: Mucosal vaccination and therapy with genetically modified lactic acid bacteria. Annu Rev Food Sci Technol 2011, 2:423-445.

108. Steidler $L$, Rottiers $P$, Coulie B: Actobiotics (TM) as a novel method for cytokine delivery the interleukin-10 case. Cytokine Therapies: Novel Approaches for Clinical Indications 2009, 1182:135-145.

109. Leblanc JG, Aubry C, Cortes-Perez NG, de Moreno de Leblanc A, Vergnolle N, Langella P, Azevedo V, Chatel JM, Miyoshi A, Bermudez-Humaran LG: Mucosal targeting of therapeutic molecules using genetically modified lactic acid bacteria: an update. FEMS Microbiol Lett 2013, 344:1-9.

110. Gardlik R, Palffy R, Celec P: Recombinant probiotic therapy in experimental colitis in mice. Folia Biol (Praha) 2012, 58:238-245.

111. Playford RJ, Marchbank T, Chinery R, Evison R, Pignatelli M, Boulton RA, Thim L, Hanby AM: Human spasmolytic polypeptide is a cytoprotective agent that stimulates cell-migration. Gastroenterology 1995, 108:108-116.

112. Vandenbroucke K, Hans W, Van Huysse J, Neirynck S, Demetter P, Remaut E, Rottiers $\mathrm{P}$, Steidler L: Active delivery of trefoil factors by genetically modified Lactococcus lactis prevents and heals acute colitis in mice. Gastroenterology 2004, 127:502-513.

113. Foligne B, Dessein R, Marceau M, Poiret S, Chamaillard M, Pot B, Simonet M, Daniel C: Prevention and treatment of colitis with Lactococcus lactis secreting the immunomodulatory Yersinia LcrV protein. Gastroenterology 2007, 133:862-874

114. Segui J, Gil F, Gironella M, Alvarez M, Gimeno M, Coronel P, Closa D, Pique JM, Panes J: Down-regulation of endothelial adhesion molecules and leukocyte adhesion by treatment with superoxide dismutase is beneficial in chronic immune experimental colitis. Inflamm Bowel Dis 2005, 11:872-882.

115. Grisham MB, Gaginella TS, von Ritter C, Tamai H, Be RM, Granger DN: Effects of neutrophil-derived oxidants on intestinal permeability, electrolyte transport, and epithelial cell viability. Inflammation 1990, 14:531-542

116. Wardman P: Fluorescent and luminescent probes for measurement of oxidative and nitrosative species in cells and tissues: progress, pitfalls, and prospects. Free Radic Biol Med 2007, 43:995-1022.

117. Carroll IM, Andrus JM, Bruno-Barcena JM, Klaenhammer TR, Hassan HM, Threadgill DS: Anti-inflammatory properties of Lactobacillus gasseri expressing manganese superoxide dismutase using the interleukin 10deficient mouse model of colitis. Am J Physiol Gastrointest Liver Physiol 2007, 293:G729-G738.

118. Han W, Mercenier A, Ait-Belgnaoui A, Pavan S, Lamine F, van S II, Kleerebezem M, Salvador-Cartier C, Hisbergues M, Bueno L, et al: Improvement of an experimental colitis in rats by lactic acid bacteria producing superoxide dismutase. Inflamm Bowel Dis 2006, 12:1044-1052.

119. Watterlot L, Rochat T, Sokol H, Cherbuy C, Bouloufa I, Lefevre F, Gratadoux J, Honvo-Hueto E, Chilmonczyk S, Blugeon S, et al: Intragastric administration of a superoxide dismutase-producing recombinant Lactobacillus casei BL23 strain attenuates DSS colitis in mice. Int J Food Microbiol 2010, 144:35-41.

120. Motta JP, Bermudez-Humaran LG, Deraison C, Martin L, Rolland C, Rousset $P$, Boue J, Dietrich G, Chapman K, Kharrat P, et al: Food-grade bacteria expressing elafin protect against inflammation and restore colon homeostasis. Sci Transl Med 2012, 4:158ra144.

121. Grangette C, Nutten S, Palumbo E, Morath S, Hermann C, Dewulf J, Pot B, Hartung T, Hols P, Mercenier A: Enhanced antiinflammatory capacity of a Lactobacillus plantarum mutant synthesizing modified teichoic acids. Proc Natl Acad Sci USA 2005, 102:10321-10326.

122. Khan MW, Zadeh M, Bere P, Gounaris E, Owen J, Klaenhammer T, Mohamadzadeh M: Modulating intestinal immune responses by lipoteichoic acid-deficient Lactobacillus acidophilus. Immunotherapy 2012, 4:151-161

123. Mohamadzadeh M, Pfeiler EA, Brown JB, Zadeh M, Gramarossa M, Managlia E, Bere P, Sarraj B, Khan MW, Pakanati KC, et al: Regulation of induced colonic inflammation by Lactobacillus acidophilus deficient in lipoteichoic acid. Proc Natl Acad Sci USA 2011, 108:4623-4630.

124. Khazaie K, Zadeh M, Khan MW, Bere P, Gounari F, Dennis K, Blatner NR, Owen JL, Klaenhammer TR, Mohamadzadeh M: Abating colon cancer polyposis by Lactobacillus acidophilus deficient in lipoteichoic acid. Proc Natl Acad Sci U S A 2012, 109:10462-10467. 
125. Zadeh M, Khan MW, Goh YJ, Selle K, Owen JL, Klaenhammer T, Mohamadzadeh M: Induction of intestinal pro-inflammatory immune responses by lipoteichoic acid. J Inflamm (Lond) 2012, 9:7. doi:10.1186/ 1476-9255-9-7. PubMed PMID: 22423982; PubMed Central PMCID: PMC3325164.

126. Hamady ZZ: Novel xylan-controlled delivery of therapeutic proteins to inflamed colon by the human anaerobic commensal bacterium. Ann $R$ Coll Surg Engl 2013, 95(4):235-40. doi:10.1308/003588413X13511609958217. PubMed PMID: 23676805.

127. Hamady ZZ, Farrar MD, Whitehead TR, Holland KT, Lodge JP, Carding SR: Identification and use of the putative Bacteroides ovatus xylanase promoter for the inducible production of recombinant human proteins. Microbiology 2008, 154(Pt 10):3165-74. doi:10.1099/mic.0.2008/019109-0. PubMed PMID: 18832322.

128. Hamady ZZ, Scott N, Farrar MD, Lodge JP, Holland KT, Whitehead T, Carding SR: Xylan-regulated delivery of human keratinocyte growth factor-2 to the inflamed colon by the human anaerobic commensal bacterium Bacteroides ovatus. Gut 2010, 59(4):461-9. doi:10.1136/gut.2008.176131. Epub 2009 Sep 7. PubMed PMID:19736360.

129. Hamady ZZ, Scott N, Farrar MD, Wadhwa M, Dilger P, Whitehead TR, Thorpe R, Holland KT, Lodge JP, Carding SR: Treatment of colitis with a commensal gut bacterium engineered to secrete human TGF-beta1 under the control of dietary xylan 1. Inflamm Bowel Dis 2011, 17:1925-1935.

130. Bron PA, van Baarlen P, Kleerebezem M: Emerging molecular insights into the interaction between probiotics and the host intestinal mucosa. Nat Rev Microbiol 2012, 10:66-U90.

131. Cummins J, MW H: Genetically modified probiotics should be banned. Microb Ecol Heal Dis 2005, 17:66-68.

doi:10.1186/1475-2859-12-71

Cite this article as: Martín et al:: Role of commensal and probiotic bacteria in human health: a focus on inflammatory bowel disease. Microbial Cell Factories 2013 12:71.

\section{Submit your next manuscript to BioMed Central and take full advantage of:}

- Convenient online submission

- Thorough peer review

- No space constraints or color figure charges

- Immediate publication on acceptance

- Inclusion in PubMed, CAS, Scopus and Google Scholar

- Research which is freely available for redistribution 